\title{
The effects of LED light spectrum manipulation on growth and color performance of giant gourami Osphronemus gouramy Lacepede Padang strain
}

\section{Manipulasi spektrum cahaya lampu LED terhadap kinerja pertumbuhan dan warna ikan gurami strain Padang Osphronemus gouramy Lacepede}

\author{
Bambang Kusmayadi Gunawan ${ }^{1}$, Kukuh Nirmala ${ }^{1 *}$, Dinar Tri Soelistyowati ${ }^{1}$, \\ Daniel Djokosetiyanto ${ }^{1}$, Wildan Nurussalam ${ }^{1}$ \\ ${ }^{1}$ Department of Aquaculture, Faculty of Fisheries and Marine Sciences, IPB University \\ *Corresponding author: kukuhni25@gmail.com
}

(Received June 13, 2017; Accepted August 10, 2017)

\begin{abstract}
This study aimed to evaluate the effect of light spectrum on growth and color performance of giant giant gourami Padang strain. The experiment used a completed randomized design (RAL) with four light emitting diode (LED) treatments in different emission spectra (white, red, green, and blue) at 550 Lux intensity, compared to the control treatment (light room with white tubular lamp at 50 Lux intensity). The irradiation was carried out for 12 hours of photoperiod. The fish used had the total length of $82.90 \pm 4.2 \mathrm{~mm}$ and body weight of $9.87 \pm 0.99 \mathrm{~g}$. The highest growth performance was found in blue LED treatment with the specific growth rate of $2.73 \pm 0.2 \%$ and feed efficiency of $86.26 \pm 2.71 \%$. The best color performance was found in red LED treatment with the RGB ratio of $44.57 \pm 0.62 \%$ in dorsal fin, $38.41 \pm 1.36 \%$ in pectoral fins, and $45.33 \pm 2.25 \%$ in anal fin with the chromatophore cell concentration at $1.973 \pm 58$ cells $/ \mathrm{mm}^{2}$.
\end{abstract}

Keywords : Osphronemus gouramy, blue LED, spectrum, chromatophore, light

\begin{abstract}
ABSTRAK
Penelitian ini bertujuan untuk mengevaluasi pengaruh spektrum cahaya terhadap kinerja pertumbuhan dan warna ikan gurami strain Padang. Rancangan penelitian yang digunakan adalah rancangan acak lengkap (RAL) dengan 4 perlakuan cahaya lampu light emitting diodes (LED) yang memiliki spektrum panjang gelombang berbeda (putih, merah, hijau dan biru) intensitas 550 Lux dan kontrol (cahaya ruang berasal dari lampu tubular putih intensitas 50 Lux). Penyinaran dilakukan selama 12 jam mengikuti fotoperiod. Ikan uji yang digunakan memiliki panjang total $82,90 \pm 4,2 \mathrm{~mm}$, dengan bobot $9,87 \pm 0,99 \mathrm{~g}$. Kinerja pertumbuhan terbaik terdapat pada perlakuan LED biru dengan laju pertumbuhan spesifik sebesar $2,73 \pm 0,2 \%$ dan efisiensi pakan sebesar $86,26 \pm 2,71 \%$. Performa warna terbaik terdapat pada perlakuan LED merah dengan rasio warna merah pada RGB bagian dorsal sebesar 44,57 \pm $0,62 \%$, sirip pektoral sebesar 38,41 $\pm 1,36 \%$, dan sirip anal sebesar $45,33 \pm 2,25 \%$ dengan jumlah sel kromatofor sebanyak $1973 \mathrm{sel} / \mathrm{mm}^{2}$.
\end{abstract}

Kata kunci : Osphronemus gouramy, LED biru, spektrum, kromatofor, cahaya 


\section{INTRODUCTION}

Giant gourami Osphronemus gourami Lacepede is a freshwater fish originated from Indonesia and known as popular high economical consumed fish. Several giant gourami strains that have been cultured by the community include Soang, Jepang, Paris, Bastar, Bluesafir, Batanghari, and Padang strains (Nugroho et al., 2013). In general, giant gourami fish has dark body color and less attractive which can only be utilized as a consumed fish. In contrast with other strains, the giant gourami Padang strain has a bright reddish color utilized not only as a consumed fish, but also attracting the fish collectors to maintain it as an ornamental fish.

The giant gourami fish population in its natural habitat is currently decreasing due to land degradation and environmental pollution based on the low number of giant gourami catch in Indonesia at 4,580 ton in 2015 (FAO, 2017). Efforts to increase the availability through culture activity could significantly produce an increased production in 2010 at 56,888 ton which increased by 113,396 ton in 2015 (FAO, 2017). These were the highest values compared to other countries that reached $97.24 \%$ of world's production in 2015 (FAO, 2017), although having a low survival rate at 50\% (Fitriadi et al., 2014; Pratama et al., 2018) and slow growth rate. Survival rate is affected by several factors, namely sex, inheritance, age, reproduction, and disease resistance. Moreover, water quality, stocking density, and feed composition also contribute to the fish survival rate level (Nugroho et al., 2015; Budiana \& Rahardja, 2018). The giant gourami breeding network multilocation test results in 2012 in Jambi, South Sumatera, and Bengkulu proved that the giant gourami Padang strain obtained the growth rate at $30 \%$ lower than the Batanghari strain (Nugroho et al., 2013). Giant gourami Padang strain is also vulnerable to stress on a fluctuate environmental condition. A fluctuate environmental condition triggers a stress condition that occurs due to metabolic energy reallocation to homeostatic improvement as supposed to be used for growth and reproduction (Pamungkas, 2012; Akbar et al., 2012).

An applicative technology to overcome the giant gourami production is an environmental manipulation such as light through spectrum manipulation or wavelength $(\lambda)$ with the light emitting diode/LED. Villamizar et al. (2009) reported that the blue LED could increase the total length of European seabass larvae. The green LED was also reported to increase the specific growth rate of clown loach at $2.35 \%$, while red LED could increase its total chromatophore cells (Aras, 2016; Nurdin, 2016). This study aimed to analyze and evaluate the environmental manipulation through LED spectrum expected to increase the growth rate and total pigment cells related to the color performance of giant gourami Padang strain.

\section{MATERIALS AND METHODS}

\section{Period and location}

This study was performed on November, 2016 to January, 2017 in the Laboratory of Aquaculture Environment III, Department of Aquaculture, FPIK, IPB University. Blood glucose, total protein serum, and blood triglyceride analyses were performed in Laboratory of Pathology, Center for Primate Studies, IPB University, while fish skin histology preparation was performed in the Laboratory of Pathology, FKH, IPB University. Furthermore, the water quality analysis was performed in the Laboratory of Aquaculture Environment III, Department of Aquaculture, FPIK, IPB University.

\section{Experimental design}

This study was performed experimentally by a completely randomized design with five LED lamp spectrum treatments and three replications for each treatment, namely four LED lamp spectrum treatments at 550 Lux intensity based on Villamizar et al. (2009) in different wavelengths: white $(\mathrm{LP}=\lambda$ peak at 465 and $550 \mathrm{~nm})$, red $(\mathrm{LM}$ $=\lambda$ peak at $625 \mathrm{~nm})$, green $(\mathrm{LH}=\lambda$ peak at 525 $\mathrm{nm})$, and blue $(\mathrm{LB}=\lambda$ peak at $450 \mathrm{~nm})$, compared to white colored-TL lamp ( $\mathrm{K}=$ room light control $)$ at 50 Lux intensity.

\section{Procedures}

The giant gourami Padang strain seeds were obtained from the giant gourami culturist in Parung, West Java. The average of fish weight used was $9.87 \pm 0.99 \mathrm{~g}$ and the average total length of $82.90 \pm 4.2 \mathrm{~mm}$. The fish test stocked in each experimental unit was 15 seeds (400 seeds $/ \mathrm{m}^{3}$ stocking density). The containers used in this study were 15 glass aquaria at $45 \times 32 \times 45$ $\mathrm{cm}^{3}$ size. The treatment on each aquarium was placed randomly. To minimize the outside light, the base, wall, and upper part of the aquaria was covered with a mulch plastic. Then, aquaria were 
filled with $36 \mathrm{~L}$ water at $3 \mathrm{~g} / \mathrm{L}$ salinity level. Each aquarium was equipped with aeration and internal filtration. The LED lamp was installed at certain height following the light intensity requirement at 550 Lux (Aras 2016). The LED lamp used was six white-colored CE 101 LED lamp bulbs at 12 volts. At the socket, a timer was installed, therefore the lamp was automatically turned on at $07.00 \mathrm{GMT}+7$ and turned off at 19.00 GMT +7 (Shin, 2012; Aras, 2016). The test fish were maintained for 60 days and fed with a commercial feed (38\% protein) with apparent satiation three times a day at 07.00, 13.00, and 19.00 GMT +7.

\section{Parameters and data analysis}

Data related to the physiological response containing oxygen consumption level, blood glucose level, total protein serum, and blood triglycerides were measured in the beginning, middle, and end of the treatment period. Meanwhile, stamina test was measured at the end of treatment period. The fish length and weight were measured once in 15 days. The growth performance data containing specific growth rate, absolute growth rate, length growth rate, feed efficiency, length and weight coefficient of variance, and survival rate, was measured at the end of treatment period. The color parameters observed were red color ratio percentage on RGB ratio and the total chromatophore cells were observed in the beginning and end of the treatment period. Water quality data containing temperature, $\mathrm{pH}$, dissolved oxygen, and salinity were measured each day, while TAN (total ammonia nitrogen) and alkalinity levels were measured once in two weeks.

The evaluated parameters in this study is presented in Table 1. Data were tabulated using a Microsoft Excel 2013. A statistical test used an analysis of variance (ANOVA) with SPSS 20.0 was performed on the growth performance and color performance data, which was continued using the Duncan's test at 95\% confidence level. The water quality data was analyzed descriptively.

\section{RESULTS AND DISCUSSIONS}

\section{Hasil}

Growth performance

The influence of LED spectrum on the growth performance of giant gourami Padang strain is presented on Table 2. The ANOVA results showed that the LED spectrum had an insignificant effect on the survival rate $(\mathrm{P}>0.05)$, but having a significant effect $(\mathrm{P}<0.05)$ on the specific growth rate (SGR), absolute growth rate (AGR), length growth rate (LGR), and feed efficiency (FE). The highest FE value was obtained from

Table 1. Parameters observed during the experiment

\begin{tabular}{lccc}
\hline \multicolumn{1}{c}{ Parameters } & Unit & Methods or measurement tool \\
\hline A. Growth performance & & \\
Survival rate (SR) & $\%$ & Sari et al. (2017); Francisca \& Muhsoni (2021) \\
Specific growth rate (SGR) & $\%$ & Schulz et al. (2005) \\
Absolute growth rate (AGR) & $\mathrm{g} /$ fish/day & Effendie (1979) \\
Length growth rate (LGR) & $\mathrm{mm}$ & NRC (1983) \\
Feed efficiency (FE) & $\%$ & Takeuchi (1988) \\
Length coefficient of variance (CV) & $\%$ & Steel and Torie (1991) \\
\hline B. Color performance & & \\
Red color ratio on RGB ratio & $\%$ & Adobe photoshop CS4 \\
(dorsal fin, pectoral fins, and anal fin) & & Aras (2015) \\
Total chromatophore cells & cells/mm & \\
\hline C. Water quality & & Thermometer and DO meter \\
Temperature & ${ }^{\circ} \mathrm{C}$ & DO meter \\
Dissolved oxygen & $\mathrm{mg} / \mathrm{L}$ & pH meter \\
pH & - & Rephractometer \\
Salinity & $\mathrm{g} / \mathrm{L}$ & Titration \\
Alkalinity & $\mathrm{mg} / \mathrm{L}$ & Spectrophotometer \\
Total ammonia nitrogen (TAN) & $\mathrm{mg} / \mathrm{L}$ &
\end{tabular}


the LB treatment at $86.26 \pm 2.71 \%$ which was significantly different from other treatments $(\mathrm{P}<0.05)$. The best growth performance was obtained from the blue LED treatment (SGR, AGR, LGR) that was significantly different from other treatments $(\mathrm{P}<0.05)$.

The weight and length growth rate indicate a positive trend during maintenance period as presented in Figure 1. All treatments on the first 30 days was in the lag phase, and exponentially increased until the 60-th day. At the end of maintenance period, the highest average weight and length growth of giant gourami Padang strain was obtained from the LB treatment at $50.26 \mathrm{~g}$ and $127.25 \mathrm{~mm}$, followed by the LP treatment at $39.94 \mathrm{~g}$ and $127.85 \mathrm{~mm}, \mathrm{LH}$ treatment at 39.91 $\mathrm{g}$ and $127.25 \mathrm{~mm}, \mathrm{LM}$ treatment at $34.58 \mathrm{~g}$ and $121.79 \mathrm{~mm}$, and $\mathrm{K}$ treatment at $35.65 \mathrm{~g}$ and $121.75 \mathrm{~mm}$.

Based on Figure 2, the LB treatment obtained the lowest $\mathrm{CV}$ value at $7.59 \pm 0.59 \%$, while the $\mathrm{LM}$ treatment obtained the highest $\mathrm{CV}$ value. The $\mathrm{CV}$ value on the LB treatment was significantly different from the LM $(18.58 \pm 1.21 \%)$, K (17.77 $\pm 5.71 \%)$, and $\mathrm{LH}(17.62 \pm 2.11 \%)$ treatments, but was insignificantly different from the LP treatment $(12.55 \pm 2.56 \%)$.
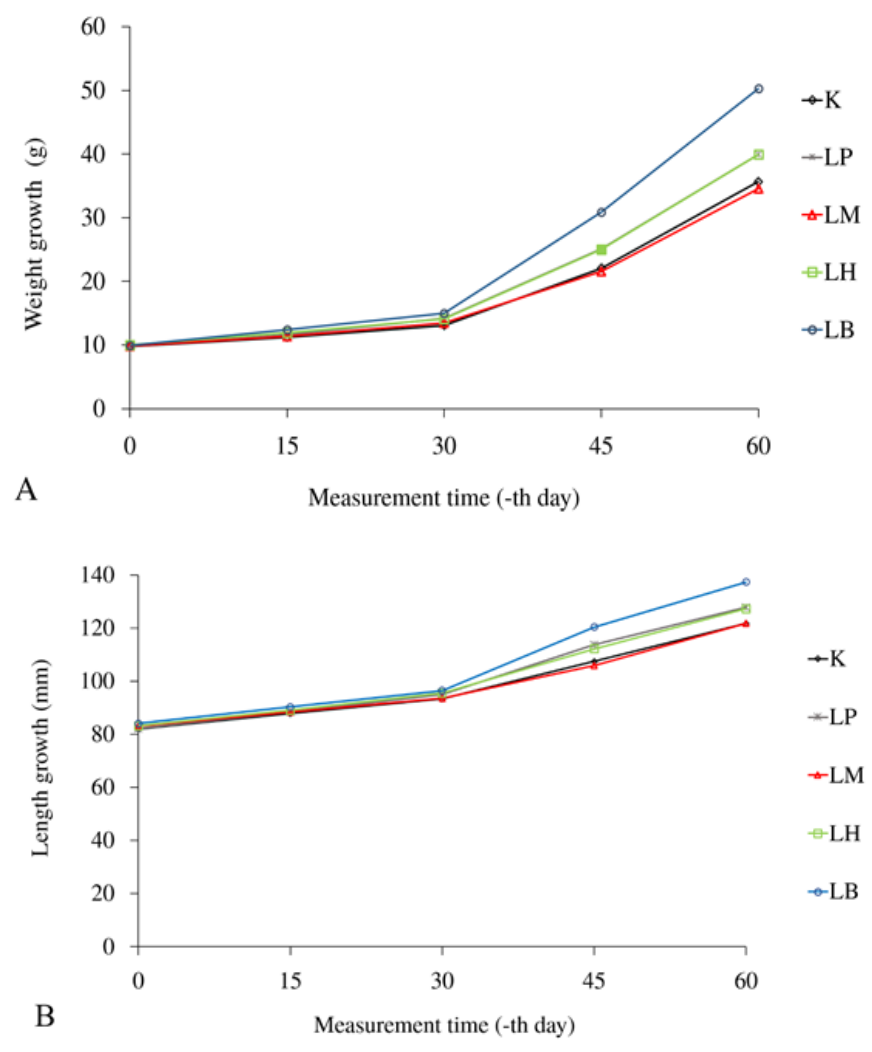

Figure 1. The average (A) Weight growth; and (B) length growth of giant gourami Padang strain Osphronemus gouramy Lac.

Table 2. Growth performance of giant gourami Padang strain Osphronemus gouramy Lac.

\begin{tabular}{cccccc}
\hline \multirow{2}{*}{ Parameter } & \multicolumn{5}{c}{ LED spectrum treatment } \\
\cline { 2 - 6 } & K & LP & LM & LH & LB \\
\hline SR (\%) & $73.33 \pm 6.67^{\mathrm{a}}$ & $82.22 \pm 3.85^{\mathrm{a}}$ & $82.22 \pm 13.88^{\mathrm{a}}$ & $71.11 \pm 7.70^{\mathrm{a}}$ & $88.89 \pm 10.18^{\mathrm{a}}$ \\
SGR (\%) & $2.18 \pm 0.14^{\mathrm{a}}$ & $2.36 \pm 0.12^{\mathrm{a}}$ & $2.11 \pm 0.15^{\mathrm{a}}$ & $2.11 \pm 0.15^{\mathrm{a}}$ & $2.73 \pm 0.20^{\mathrm{b}}$ \\
AGR & & & & & \\
(g/fish/day) & $0.43 \pm 0.05^{\mathrm{a}}$ & $0.50 \pm 0,06^{\mathrm{a}}$ & $0.41 \pm 0.05^{\mathrm{a}}$ & $0.50 \pm 0.08^{\mathrm{a}}$ & $0.67 \pm 0.10^{\mathrm{b}}$ \\
LGR (mm) & $39.86 \pm 3.36^{\mathrm{a}}$ & $45,69 \pm 3.91^{\mathrm{a}}$ & $38.83 \pm 2.54^{\mathrm{a}}$ & $44.06 \pm 5.25^{\mathrm{a}}$ & $54.25 \pm 4.41^{\mathrm{b}}$ \\
FE (\%) & $66.28 \pm 2.36^{\mathrm{b}}$ & $68.94 \pm 2.38^{\mathrm{b}}$ & $56.48 \pm 1.69^{\mathrm{a}}$ & $68.97 \pm 0.83^{\mathrm{b}}$ & $86.26 \pm 2.71^{\mathrm{c}}$ \\
\hline
\end{tabular}

aifferent superscript letters on the same line show a significant difference (Duncan's test; $\mathrm{P}<0.05$ ). Values are presented in the average and standard deviation values. $\mathrm{K}=$ room light control; $\mathrm{LP}=$ white $\mathrm{LED}$; $\mathrm{LM}=$ red LED; $\mathrm{LH}=$ green LED; $\mathrm{LB}=$ blue LED . 


\section{Color quality}

The ANOVA results showed that the LED spectrum treatments could significantly influence the red color ratio percentage on the RGB ratio as presented in Table 3. Samples from dorsal fin, pectoral fins, and anal fin obtained the highest values on the red LED treatment that was also significantly different from other treatments $(\mathrm{P}<0.05)$.

The increased color performance based on the increased total chromatophore cells on the dorsal fin is presented in Figure 3. The ANOVA results showed that the LED spectrum significantly influence the total chromatophore cells with the highest value was obtained from the red LED treatment at 1.973 cells $/ \mathrm{mm}^{2}$ which was significantly different from other treatments $(\mathrm{P}<0.05)$.

Increased color performance based on the red percentage in the RGB ratio and total chromatophore cells on all treatments indicates a chromatophore cell movement to certain body parts that are exposed to the light (presented in Figure 4), whereas the LM and LB treatments were observed to have chromatophore cells concentrated in a certain area, contradictory to other treatments which had distributed chromatophore cells.

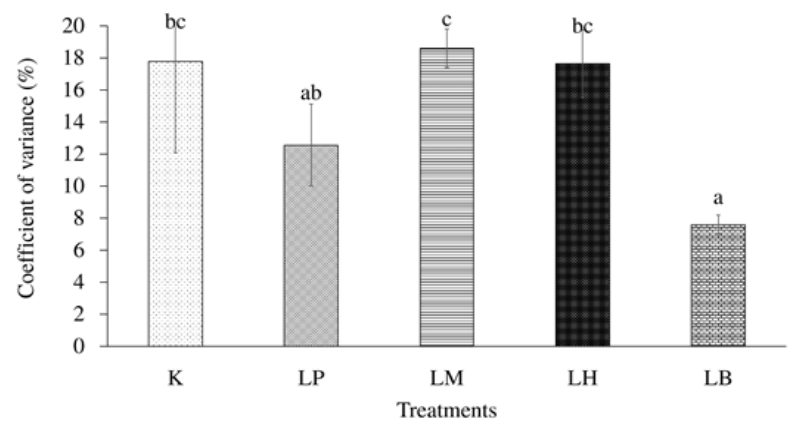

Figure 2. The length coefficient of variance on giant gourami Padang strain Osphronemus gouramy Lac. at the end of maintenance period for 60 days. $\mathrm{K}=$ (control) room light; $\mathrm{LP}=$ white $\mathrm{LED}$; $\mathrm{LM}=$ red LED; $\mathrm{LH}=$ green LED; $\mathrm{LB}=$ blue LED.

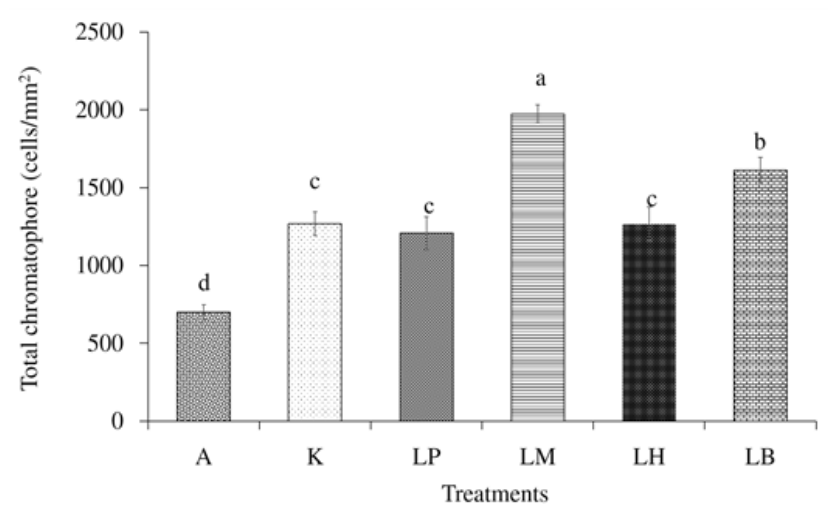

Figure 3. Total chromatophore cells on giant gourami Padang strain Osphronemus gouramy Lac. (a) Fish before treatment; (b) K= room light control; (c) LP = white LED; (d) LM = red LED; (e) LH = green LED; and (f) LB $=$ blue LED.

Table 3. The red ratio percentage on the RGB ratio in three body parts of giant gourami Padang strain Osphronemus gouramy Lac.

\begin{tabular}{cccc}
\hline Treatment & Dorsal fin & Pectoral fins & Anal fin \\
\hline A & $37.35 \pm 2.26^{\mathrm{bc}}$ & $34.27 \pm 1.73^{\mathrm{b}}$ & $39.65 \pm 3.28^{\mathrm{b}}$ \\
K & $37.90 \pm 0.78^{\mathrm{bc}}$ & $34.30 \pm 0.20^{\mathrm{b}}$ & $36.65 \pm 0.52^{\mathrm{b}}$ \\
LP & $39.17 \pm 1.18^{\mathrm{b}}$ & $35.33 \pm 0.30^{\mathrm{b}}$ & $38.28 \pm 0.71^{\mathrm{b}}$ \\
LM & $44.57 \pm 0.62^{\mathrm{a}}$ & $38.41 \pm 1 ., 36^{\mathrm{a}}$ & $45.33 \pm 2.25^{\mathrm{a}}$ \\
LH & $36.99 \pm 0.94^{\mathrm{bc}}$ & $34.20 \pm 0.40^{\mathrm{b}}$ & $37.11 \pm 0.91^{\mathrm{b}}$ \\
LB & $36.71 \pm 0.81^{\mathrm{c}}$ & $34.65 \pm 0.70^{\mathrm{b}}$ & $37.15 \pm 0.71^{\mathrm{b}}$ \\
\hline
\end{tabular}

$\bar{a}$ Different superscript letters on the same line show a significant difference (Duncan's test; $\mathrm{P}<0.05$ ). Values are presented in the average and standard deviation values. $\mathrm{K}=$ room light control; $\mathrm{LP}=$ white $\mathrm{LED}$; $\mathrm{LM}=$ red LED; $\mathrm{LH}=$ green LED; LB = blue LED . 


\section{Water quality}

The water quality measurement results for 60 days of maintenance is presented in Table 4. The temperature in all treatments was among $29.5-32.5^{\circ} \mathrm{C}$. The oxygen concentration was generally among $3.3-4.8 \mathrm{mg} / \mathrm{L}$. The $\mathrm{pH}$ values in all treatment were among 5.17-8.72. The salinity value showed a relatively stable and uniform value at $3 \%$. The highest alkalinity level was obtained from the LP treatment at $210.21-270.27 \mathrm{mg} / \mathrm{L}$, while the lowest alkalinity level was obtained from the LM treatment at $180.18-280.28 \mathrm{mg} / \mathrm{L}$. The TAN values in all treatments were among 0.094-0.57 mg/L.

\section{Discussions}

The best growth performance results were from the blue LED treatment which was also found in Illamizar et al. (2009). The blue LED light spectrum increased the total length of seabass larvae at kakap $15.4 \pm 0.6 \mathrm{~mm}$ and weight of 21.6 $\pm 2.02 \mathrm{mg}$, which was significantly different from other color spectrum treatments. This condition was caused as giant gourami was more capable of detecting the blue light with short wavelength following its natural habitat. Also, it was also observed from the results presented in the table that the LB treatment was significantly different from other treatments.

Light is extremely important for most organisms. The light spectrum penetration to the waters is less than to the land due to selective absorption by natural water components. Therefore, a spectral distribution from the light to the eyes from an object in the water depends on the object distance to the eyes, and the object detection depends on the light from the object relative against the background that can be seen to produce the best visual with a maximum wavelength ( $\lambda$ max) that can be absorbed as a correction result from the light wavelength that penetrates the water (Loew \& Lythgoe, 1978).

In diurnal fish, a visual capability is the main censor for feeding activity and protection strategy, as photoreceptor cells in fish have been proved the color discrimination theory in fish (Ayyubi et al., 2019; Escobar-Camacho et al., 2019). The photoreceptor cells contain two types, namely cones and rods. Cones are cone cells responsible for bright vision and color differential, while rods are rod cells responsible for low vision and bright level information provider (Vinberg et al., 2018; Zang \& Neuhauss, 2021). Several freshwater fish species are included in a blue-sensitive cone that only have one cone cell with dominated rod cells (Nabiu et al., 2018). These fish are extremely sensitive on short blue light wavelength (460 $\mathrm{nm}$ ), which can absorb blue color more optimally than other colors (Loew \& Lythgoe, 1978). This condition also occurred on the giant gourami as this study object. A deeper study regarding light influence on fish endocrinal system found that there was an association between blue light ( $\lambda$ 434-477 nm) and increased melatonin level production in seabass fish. Shin et al. (2012) emphasized that a higher GH-RNA expression level in fish pituitary of clownfish Amphiprion clarkia after being injected with melatonin on blue and green light treatments than on red light treatment. This was thought was melatonin stimulated the GH secretion as a growth promoter.

Feed efficiency (FE) is a successive indicator for feed utilization. The higher feed efficiency value, the less feed requirement to produce one kilogram of fish flesh as the feed can utilized optimally for growth. Rahmawati et al. (2016) stated light could influence the feeding activity and stimulate the feed consumption level in fish. This study also concluded that light exposure at night could decrease the feed conversion ratio. Low feed conversion ratio means that the fish can utilize the feed more efficiently and suppress the feed cost. In addition, Setiawati et al. (2013) clarified that a good feed efficiency could provide a greater energy availability which implicated on the increased energy level used for growth support. Rahmwati et al. (2016) showed that the 24-hour light produced the lowest feed conversion level at $1.45 \pm 0.12$, followed by the highest absolute weight growth, growth rate, and survival rate of tambaqui Colossoma macropomum. Elsbaay (2013) showed that the use of blue spectrum on Nile tilapia obtained the lowest feed conversion at $1.04 \pm 0.01$ and $\mathrm{FE}$ value at $96.15 \%$ as significantly different from other treatments. Difference among the treatments were occurred due to the stimuli acceptance and wavelength tolerable differences.

Different LED lamp spectra affected the length coefficient of variance $(\mathrm{CV})$ in test fish $(\mathrm{P}<0.05)$. The $\mathrm{CV}$ values were variative in each treatment as thought due to associated with high stocking density applied in this study which was five times higher than the traditional culture (SNI, 2000), besides the giant gourami character as a territorial fish. The higher stocking density, the narrower movement space, resulting in space and feed competition that leads to domination and 
hierarchical structure in the community. Several individuals showed a faster adaptability which could grow faster, while other individuals were less adaptable that led to stress condition and slow growth (Folnuari et al., 2017; Sihite et al., 2020).

Light intensity, spectrum, light duration, and photoperiod can be organized to control the fish growth (Heydarnejad et al., 2013; LopezBetancur et al., 2020). The lowest CV value was obtained from the blue LED treatment which indicates that the blue light can suppress the stress level in giant gourami Padang strain, therefore the energy gained from the feed can be utilized optimally for growth. This condition was emphasized by Ninwichian et al. (2018) who stated that the snakeskin gourami Trichogaster pectoralis maintained in a blue tank produced a better growth, a lower feed conversion, a lower cortisol level, and a lower plasme glucose level. This condition was also reported by Ebrahimi (2011) who studied the application of blue tank for guppy Poecilia reticulata growth. Kawamura et al. (2017) also proved that the blue light could inhibit stress on red sea bream juvenile due to low plasma glucose level in blue light treatment, compared to red, green, and white light treatments.

Color quality measurement using the RGB model is more efficient and easier, besides can potentially provide an early detection on the feed impact in color quality and fish phenotypic differences (Novita et al., 2019). The RGB model can presented as a three-dimensional space that describes the exposed colors based on three main colors (Rulaningtyas et al., 2015; Prabowo et al., 2018). This model is an additive model as all color spectra from $380 \mathrm{~nm}$ to 780 $\mathrm{nm}$ can be formed by mixing the three primary colors in different proportions to produce more than 16 million colors (Lustini et al., 2019; Rabbani et al., 2021). Chromatophore cells increased along with the fish age based on the low total chromatophore cells at the beginning of maintenance period $\left(699\right.$ cells $\left./ \mathrm{mm}^{2}\right)$ that increase at the end of maintenance period in all treatments. In teleost fish, chromatophore cells are originated from multipotential pigment cell precursors produced by neural crest cell part formed during embryogenesis (Parichy \& Spiewak, 2015; Petratou et al., 2021). Chromatophores are responsible for providing the skin color in various species. Lately, there are six chromatophore cells known to be available in fish, namely melanophore for black or chocolate pigmentation, xanthophore for yellow pigmentation, erythrophore for red pigmentation, leucophore for white pigmentation, iridophore for metallic pigmentation associated with color change, and cyanophore for blue pigmentation (Cal et al., 2017; Djurdjevič et al., 2019; Luo et al., 2021).

Figure 4 presents the concentrated chromatophore cells in a certain area on the LM and LB treatment. In contrast, other treatments present distributed chromatophore cells. This condition may be caused by the chromatophore cells that have motor protein as movement tool (Salmon et al., 2019). Chromatophore cells are
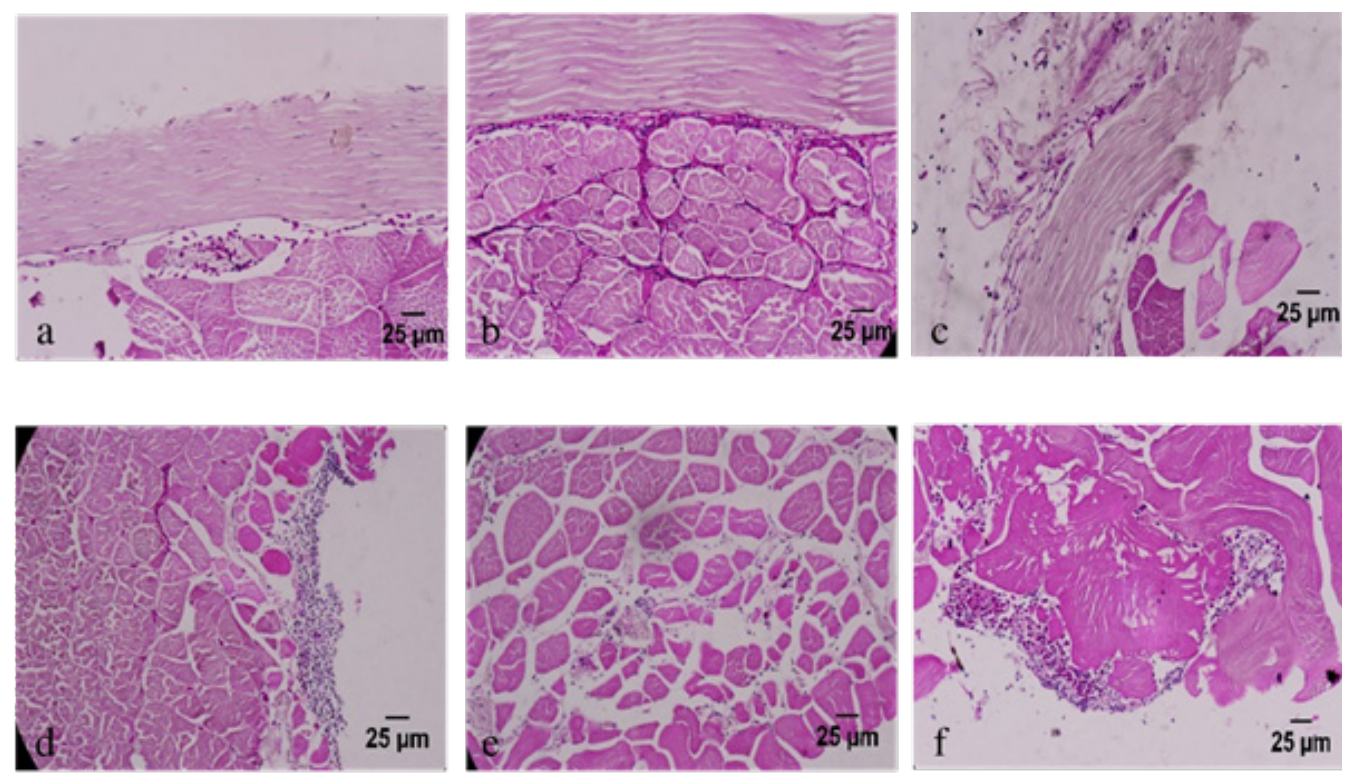

Figure 4. Histological condition of chromatophore cell distribution in giant gourami Padang strain. (a) Fish before treatment; (b) K= room light control; (c) LP = white LED; (d) LM = red LED; (e) LH = green LED; and (f) LB = blue LED. 
extremely sensitive on a certain light wavelength. Oshima and Yokozeki (1999) proved that erythrophore was very sensitive against either longer wavelength (550-600 $\mathrm{nm})$ or shorter wavelength (400-440 nm). In these wavelengths, erythrophore cells were aggregated, contradictory in the $470-530 \mathrm{~nm}$ wavelength as the erythrophore cells tended to be dispersed.

In this study, the blue LED obtained a wavelength of 400-470 nm with the peak wavelength at $450 \mathrm{~nm}$, and red LED was in $550-700 \mathrm{~nm}$ with the peak wavelength at 625 $\mathrm{nm}$, while green LED was in 470-575 nm with the peak wavelength at $525 \mathrm{~nm}$, and white LED was in 400-700 $\mathrm{nm}$ with two peak wavelengths at 465 and $550 \mathrm{~nm}$. The range of LED lamp wavelength used was nearly closed with the range value by Oshima and Yokozeki (1999), which was thought as the increased total chromatophore cells on each observation field in the LM and LB treatments was due to chromatophore cell aggregation, contradictory with LH, LP, and $\mathrm{K}$ treatments that obtained low total chromatophore cells due to chromatophore cell dispersion. The chromatophore cell aggregation and dispersion can be directly caused by light exposure (primary response) or nerve and endocrinal mechanisms (secondary response). In the first case, chromatophores react as independent receptors and effectors, transmitting the light energy in the pigment migration mechanism process or guanin crystal simultaneous movement which causes color change in the integument.

In general, all treatment media had a normal temperature level at $25-30^{\circ} \mathrm{C}$ (SNI, 2000). The dissolved oxygen level based on the measurement results was in the tolerable limit by the giant gourami. Although the temperature almost reached a temperature of $33^{\circ} \mathrm{C}$ at the beginning of maintenance period, the giant gourami could still tolerate it, following Pratama et al. (2018) who reported that the temperature used for maintenance was among $28-32^{\circ} \mathrm{C}$. The dissolved oxygen level in the maintenance media were in the suggested tolerable limit at $4 \mathrm{mg} / \mathrm{L}$ (Riza et al., 2015), but not becoming a limiting factor for giant gourami. Giant gourami can live in low dissolved oxygen level (Akbar et al., 2013; Jumaidi et al., 2017).

The $\mathrm{pH}$ value in all treatments were in an optimal $\mathrm{pH}$ value range at 6.5-8.5 (SNI, 2000). Salinity was remained at $3 \mathrm{~g} / \mathrm{L}$ each day following Marda et al. (2015) to maintain an isosmotic condition between fish body and environment, therefore the energy release for osmoregulation can be minimized. The alkalinity level in all treatments were in a suggested range limit at $50-400 \mathrm{mg} / \mathrm{L}$ and the TAN value was generally in a normal range recommended by Wahyuningsih and Gitarama (2020) which was less than 1.5 $\mathrm{mg} / \mathrm{L}$. The use of internal filter, syphonization activity performed every day, water exchange, and frequent water quality measurement could maintain the water quality level in an optimal range, which produced the water as maintenance medium in this study was in a qualified condition for optimal growth support of the test fish.

\section{CONCLUSIONS}

Environmental manipulation with light spectra can improve the growth and color performance of giant gourami Padang strain. The best growth performance was obtained from the blue LED treatment with the peak $\lambda$ of $470 \mathrm{~nm}$ based on the SGR, AGR, LGR, PE, and CV values. The best color performance was obtained from the red LED treatment with the peak $\lambda$ of $625 \mathrm{~nm}$ based on the red color percentage on RGB ratio and total chromatophore cells.

\section{REFERENCES}

Akbar J, Fauzana NA, Aisiah S, Adriani M. 2012. Growth and feed efficiency of climbing perth on the diets containing various chromium content. Torani (Jurnal Ilmu Kelautan dan Perikanan) 22: 79-89.

Akbar YA, Agustono, Kusdarwati R. 2013. The granting of an enzyme lignosellulosa in feed artificial on the growth and the survival rate seed gourami Osphronemus gouramy Lac.. Jurnal Ilmiah Perikanan dan Kelautan 5: 163166.

Aras AK. 2016. Manipulasi spektrum cahaya terhadap pertumbuhan dan kualitas warna ikan botia Chromobotia macracanthus Bleeker. Jurnal Ikhtiologi Indonesia 16: 45-55.

Ayyubi H, Budiharjo A, Sugiyarto. 2019. Morphological characteristics of silver barb fish population Barbonymus gonionotus (Bleeker, 1849) from different waters locations in Central Java Province. Jurnal Iktiologi Indonesia 19: 65-78.

Budiana, Rahardja BS. 2018. Gouramy Osphronemus gouramy breeding techniques at Fish Seed Center Ngoro, Jombang. Journal of Aquaculture and Fish Health 7: 90-97. 
Cal L, Suarez-Bregua P, Cerdá-Reverter JM, Braasch I, Rotllant J. 2017. Fish pigmentation and the melanocortin system. Comparative Biochemistry and Physiology Part A: Molecular \& Integrative Physiology 211: 2633.

Effendie MI. 1979. Metode Biologi Perikanan. Bogor (ID): Yayasan Dewi Sri.

Elsbaay AM. 2013. Effect of photoperiod and different artificial light color on nila tilapia growth rate. IOSR Journ of Agr and Vet Sci. 3: 5-12.

Escobar-Camacho D, Taylor MA, Cheney KL, Green NF, Marshall NJ, Carleton KL. 2019. Color discrimination thresholds in a cichlid fish: Metriaclima benetos. Journal of Experimental Biology 222: jeb201160.

Djurdjevič I, Furmanek T, Miyazawa S, Bajec SS. 2019. Comparative transcriptome analysis of trout skin pigment cells. BMC Genomics 20: 359.

Ebrahimi G. 2011. Effects of rearing tank background color on growth performance in juvenile common carp, Cyprinus carpio. L. Agricultural Journal 6: 213-217.

[FAO] Food and Agriculture Organization. 2017. Fisheries and Aquaculture Information and Statistics Branch. [Internet]. [diunduh 2017 Mei 04]. Tersedia pada http://www. fao.org/figis/servlet/SQServlet?file=/ work/FIGIS/prod/webapps/figis/ temp/hqp_7397846914380657296. $\mathrm{xml}$ \&outtype $=\mathrm{html}$.

Fitriadi WM, Basuki F, Nugroho RA. 2014. The effect of recombinant growth hormone ( $\mathrm{rGH})$ through oral methods with different time intervals of the survival and growth of giant gouramy larvae var Bastard Osphronemus gouramy Lac, 1801. Journal of Aquaculture Management and Technology 3: 77-85.

Folnuari S, El Rahimi SA, Rusydi I. 2017. Effect of different stocking densities on survival and growth of cantang grouper Epinephelus fuscoguttatus-lanceolatus in HDPE cagenets. Jurnal Ilmiah Mahasiswa Kelautan dan Perikanan Unsyiah 2: 310-318.

Novita RD, Nirmala K, Suoriyono E, Ardi I. 2019. Efektivitas paparan spektrum cahaya lampu Light Emitting Diode (LED) terhadap pertumbuhan dan kualitas warna yuwana ikan badut, Amphiprion percula (Lacèpède, 1802). Jurnal Riset Ikhtiologi Indonesia 19: 127-141.

Heydarnejad MS, Parto M, Pilevarian AA. 2013. Influence of light colours on growth and stress response of rainbow trout Oncorhynchus mykiss under laboratory conditions. Journal of Animal Physiology and Animal Nutrition 97: 67-71.

Jumaidi A, Yulianto H, Efendi E. 2017. Pengaruh debit air terhadap perbaikan kualitas air pada sistem resirkulasi dan hubungannya dengan sintasan dan pertumbuhan benih ikan gurame Oshpronemus gourami. e-Jurnal Rekayasa dan Teknologi Budidaya Perairan 5: 587-596.

Kawamura G, Bagarinao TU, Anraku K, Okamoto M. 2017. Effect of colored light regimes on the stress response and RNA/DNA ratio of juvenile red sea bream, Pagrus major. Borneo Journal of Marine Science and Aquaculture 1: 33-38.

Loew ER, Lythgoe JN. 1978. The ecology of cone pigments in teleost fishes. Vision research 18: 715-722.

Lopez-Betancur D, Moreno I, Guerrero-Mendez C, Gómez-Meléndez D, de J. Macias PM, Olvera-Olvera C. 2020. Effects of colored light on growth and nutritional composition of tilapia, and biofloc as a food source. Applied Science 10: 362.

Luo M, Lu G, Yin H, Wang L, Atuganile M, Dong Z. 2021. Fish pigmentation and coloration: Molecular mechanisms and aquaculture perspectives. Reviews in Aquaculture 00: $1-18$.

Lustini A, Saparudin, Primanita A. 2019. The classification of pineapple's level of ripeness using colour space red - green - blue and hue saturation - intensity. Jurnal Digital Teknologi Informasi 2: 1-8.

Marda AB, Nirmala K, Harris E, Supriyono E. 2015. Efektivitas fitoremediator Lemna perpusilla pada media budidaya ikan gurami bersalinitas 3 ppt. Jurnal Akuakultur Indonesia 14: 122-127.

Nabiu NLM, Baskoro MS, Zulkarnain, Yusfiandayani R. 2018. Light adaptation process of retinal yellowstripe scad Selaroides leptolepsis. Jurnal Teknologi Perikanan dan Kelautan 9: 97-102.

Ninwichian P, Phuwan N, Jakpim K, Sae-Lim P. 2018. Effects of tank color on the growth, stress responses, and skin color of snakeskin gourami Trichogaster pectoralis. Aquaculture International 26: 659-672.

[NRC] National Research Council. 1983. Nutrient Requirement of Warmwater Fishes and Shellfishes. Washington DC (US): National Academy of Science. 
Nugroho E, Rahayuni E, Hamid MA. 2013. Gurami Batanghari: benarkah strain berbeda? Suatu kajian genetik dengan menggunakan marker DNA. Media Akuakultur 8: 9-12.

Nugroho II, Subandiyono, Herawati VE. 2015. Tingkat pemanfaatan Artemia sp. beku, Artemia sp. awetan dan cacing sutera untuk pertumbuhan dan kelangsungan hidup larva ikan gurami Osphronemus gouramy Lac.. Journal of Aquaculture Management and Technology 4: 117-124.

Nurdin M. 2015. Perbedaan lama penyinaran dan intensitas cahaya terhadap pertumbuhan serta sintasan benih ikan tengadak Barbonymus schwanenfeldii. Jurnal Riset Akuakultur 10: 371-378.

Oshima N, Yokozeki A. 1999. Direct control of pigment aggregation and dispersion in tilapia erythrophores by light. Zoological Science 16: 51-54.

Pamungkas M. 2012. Aktivitas osmoregulasi, respons pertumbuhan, dan energetic cost pada ikan yang dipelihara dalam lingkungan bersalinitas. Media Akuakultur 7: 44-51.

Parichy DM, Spiewak JE. 2015. Origins of adult pigmentation: diversity in pigment stem cell lineages and implications for pattern evolution. Pigment Cell Melanoma Research 2015 January 28: 31-50.

Petratou K, Spencer SA, Kelsh RN, Lister JA. 2021. The MITF paralog tfec is required in neural crest development for fate specification of the iridophore lineage from a multipotent pigment cell progenitor. PLoS ONE 16: e0244794.

Prabowo DA, Abdullah D, Manik A. 2018. Deteksi dan perhitungan objek berdasarkan warna menggunakan color object tracking. Jurnal Pseudocode V: 85-91.

Pratama BA, Susilowati T, Yuniarti T. 2018. The effect of different temperature in eggs hatching time, hatching rate, survival rate and growth of gourami fish Osphronemus gouramy strain Bastar. Jurnal Sains Akuakultur Tropis 2: 5965.

Rabbani A, Rahman MA, Rahayudi B. Perbandingan ruang warna RGB dan HSV dalam klasifikasi kematangan biji kopi haidar. 2021. Jurnal Pengembangan Teknologi Informasi dan Ilmu Komputer 5: 2243-2248.

Rahmawati APA, Hudaidah S, Wijayanti $\mathrm{H}$. 2016. Pengaruh intensitas cahaya selama pemeliharaan benih ikan kerapu macan Epinephelus fuscoguttatus. e-Jurnal Rekayasa dan Teknologi Budidaya Perairan 5: 547-558

Riza F, Bambang AN, Kismartini. 2015. Tingkat pencemaran lingkungan perairan ditinjau dari aspek fisika, kimia dan logam di Pantai Kartini Jepara. Indonesian Journal of Conservation 4: 52-60.

Rulaningtyas R, Suksmono AB, Mengko TLR, Putri Saptawati GA. 2015. Segmentasi citra berwarna dengan menggunakan metode clustering berbasis patch untuk identifikasi Mycobacterium tuberculosis. Jurnal Biosains Pascasarjana 17: 19-25.

Salmon AR, Cornier S, Wang W, Abell C, Baumberg JJ. 2019. Light-triggered nanoparticles for microdroplet locomotion and color change. Advanced Optical Materials 7: 1900951.

Schulz C, Knaus U, Wirth M, Rennert B. 2005. Effect of varying dietary fatty acid profile on growth performance, fatty acid, body and tissue composition of juvenile Pike perch Sander lucioperca. Aquaculture 11: 403-413.

Sihite ER, Rosmaiti, Putriningtias A, Putra ASA. 2020. Effect of high stocking density water quality and growth of goldfish Cyprinus carpio with the addition nitrobacter. Jurnal Ilmiah Samudra Akuatika IV: 10-16.

Setiawati JE, Tarsim, Adiputra YT, Hudaidah S. 2013. Pengaruh penambahan probiotik pada pakan dengan dosis berbeda terhadap pertumbuhan, kelulushidupan, efisiensi pakan dan retensi protein ikan patin. Jurnal Rekayasa dan Teknologi Budidaya Perairan 1: 23023600.

Shin HS, Lee J, Choi CY. 2012. Effects of LED light spectra on oxidative stress and the protective role of melatonin in relation to the daily rhythm of the yellowtail clownfish, Amphiprion clarkii. Comp Biochem and Physiol, Part A. 160: 221-228.

[SNI] Standar Nasional Indonesia. 2000. Produksi benih ikan gurami (Osphronemus goramy, Lac) kelas benih sebar. SNI 01-6485.3-2000. Jakarta (ID): Badan Standarisasi Nasional.

Steel GD, JH Torrie. 1991. Prinsip-prinsip dan Prosedur Statistika. Terjemahan PT. Gramedia Pustaka Utama, Jakarta.

Takeuchi T. 1988. Laboratory Work Chemical Evaluation of Dietary Nutrients, In: Fish Nutrition and Mariculture, Watanabe T (ed). 
Tokyo University of Fisheries: Department of Aquatic Bioscience. p 179-225.

Villamizar N, Alcazar AG, Vazquez FJS. 2009. Effect of light spectrum and photoperiod on the growth, development and survival of European sea bass Dicentrarchus labrax larvae. Aquaculture $292: 80-86$.

Vinberg F, Chen J, Kefalov VJ. 2018. Regulation of calcium homeostasis in the outer segments of rod and cone photoreceptors. Progress in Retinal and Eye Research 67: 87-101.

Wahyuningsih S, Gitarama AM. 2020. Amonia pada sistem budidaya ikan. Syntax Literate : Jurnal Ilmiah Indonesia 5: 112-125.

Zang J, Neuhauss SCF. 2021. Biochemistry and physiology of zebrafish photoreceptors. Pflügers Archiv-European Journal of Physiology 473: 1569-1585. 